\title{
Nematode and Cestode Prevalence, Organal Distribution and Histological Effects Due to Parasitic Infection in Laboratory Rat Strain, Long-Evans (Rattus norvegicus Berkenhout, 1769)
}

\author{
Hamida Khanum $^{\mathrm{a}}$, Farhana Muznebin ${ }^{\mathrm{a} *}$ and Zaibun Nessa ${ }^{\mathrm{b}}$ \\ ${ }^{a}$ Department of Zoology, University of Dhaka, Dhaka-1000, Bangladesh and \\ ${ }^{b}$ Institute of Food Science and Technology, BCSIR, Dhaka-1205, Bangladesh.
}

\begin{abstract}
Endoparasitic infection and histopathological effects in the laboratory rat, Long-Evans (Rattus norvegicus Berkenhout 1769) was evaluated. Five species of helminth parasites from two taxonomic groups were identified. They were -Cestodes (Vampirolepis nana Siebold, 1852 and Hymenolepis diminuta Rudolphi, 1819) and Nematodes (Citellina dispar Prendel, 1928; Heterakis spumosa Schneider, 1866 and Syphacia muris Yamaguti, 1941). All the worms were collected from the alimentary tract of the Long-Evans. The prevalence of infection was found highest in caecum (95.83\%) and the intensity of infestation was found highest in anterior parts of the intestine (51.33 \pm 10.63 ). The histopathological study of helminth infected alimentary canal showed that the intestinal wall was severely damaged.
\end{abstract}

Key words: Nematodes, Cestodes, Prevalence, Vampirolepis nana, Hymenolepis diminuta, Citellina dispar, Heterakis spumosa and Syphacia muris.

\section{Introduction}

Rats and mice harbor a number of helminth parasites, which can be transmitted to man and other vertebrates (Oldham, 1931). Helminth parasitized rats were studied to identify the species and for determination of prevalence and intensity of helminths (Stanly and Virgin, 1993; Alam et al., 2003; Khanum and Arefin, 2003).

Cestode and nematode parasites in rat have been reported from all parts of the world. Vampirolepis nana and Hymenolepis diminuta are commonly found in rats and mice and potentially transmissible (Zoonoses) to man. The occurrence of $H$. diminuta and $V$. nana in certain rodents is of interest since the possibility exists that rats and mice may serve as reservoir hosts and aid in the dissemination of these worms to domestic animals and man (Jawdat and Mahmoud, 1980); causing zoonoses.

In Bangladesh, several studies have been carried out on identification of the parasites of rats and mice but no histopothological investigation have been done (Huq, 1969; Shaha, 1974; Bhuiyan et al., 1996; Alam et al., 2003 and; Khanum and Arefin, 2003). The effects of parasites on their host can also be examined by pathological condition. Inspite of several pathological works on parasitic infestation in our country no pathological investigation have so far been undertaken on histopathology of the infestation on Long-Evans.

The present study was carried out on identification of parasite species prevalence and histopathological effect of parasites on their host and for securing additional information on the helminth parasites of laboratory rat.

\section{Materials and Methods}

During the study period from April 2007 to March 2008 a total of 48 Long-Evans were collected weekly and monthly basis from Animal Research Section of the Institute of Food Science and Technology (IFST) of Bangladesh Council of Scientific and Industrial Research (BCSIR), Dhaka. To collect the parasites tested Long-Evans were dissected, the viscera were collected and brought to the parasitology laboratory of the Department of Zoology, University of Dhaka.

A histopathological investigation was carried out on thin sections of tissues. Then permanent slides were prepared from the tissues and permanent slides were prepared by Cable, 1963.

\footnotetext{
*Corresponding Author, Email: farhana_zoologydu@yahoo.com.
} 


\section{Results and Discussion}

The intestine of the Long-Evans (Rattus norvegicus) was infested by cestode parasites Vampirolepis nana (Siebold, 1852) and Hymenolepis diminuta (Rudolphi, 1819) and nematodes Citellina dispar (Prendel, 1928); Heterakis spumosa (Schneider, 1866) and Syphacia muris (Yamaguti, 1941).

A total of 1643 nematodes were collected from 46 infested hosts and 1911 cestodes from 38 infested hosts. The prevalence of cestodes and nematodes were $79.17 \%$ and $95.83 \%$ respectively. Prevalence of nematodes was higher than the cestodes. Intensity of cestodes and nematodes were 50.29 \pm 14.13 and $35.71 \pm 7.89$ respectively.

The parasites were most abundant in anterior part of intestine. No parasites were found in stomach. In duodenum 46 (43.75\%) parasites were collected and 1848 (75\%) parasites were collected from anterior intestine, 729 (77.08\%) parasites from posterior intestine and 931 (95.83\%) parasites were collected from caecum. Lower intensity of infestation was found in duodenum (2.19 \pm 0.42$)$. The highest intensity was found in anterior intestine (51.3 \pm 10.63$)$. Slightly higher intensity of infestation was found in caecum (20.23 \pm 2.60$)$ and in posterior intestine (19.70 \pm 2.37$)$ respectively (Table I).

In species mix distribution the highest prevalence of $V$. nana was recorded from anterior intestine (53.33\%). While, lower prevalence was found in duodenum (41.66\%). The highest prevalence of $H$. diminuta was found also in anterior intestine (50\%). The lower prevalence was recorded in duodenum $4.16 \%$ and in posterior intestine (4.17\%). But duodenum and caecum contain higher and equal prevalence (20.83\%). On the other hand, $0 \%$ prevalence was found in stomach, duode num and anterior intestine in case of $C$. dispar, $H$. spumosa and $S$. muris. The highest prevalence of $C$. dispar was found in caecum $(60.42 \%)$ and comparatively lower in posterior intestine (52.08\%). But the highest prevalence (62.50\%) was found in caecum both in case of $H$. spumosa and $S$. muris. The lower prevalence of them was found in posterior intestine $39.58 \%$ and $54.17 \%$ respectively.

The intensity of $V$. nana showed the highest intensity in anterior intestine (61.71) while, parasites were totally absent in stomach, posterior intestine and caecum. Lower intensity was found in duodenum (2.2). The highest intensity of $H$. diminuta was found in anterior intestine (5) and lower intensity (1) was found in duodenum, posterior intestine and caecum. The highest intensity of $C$. dispar and $S$. muris were found in caecum (11.79 and 13.83) and slightly lower intensity was found in posterior intestine (9.88 and 13.42). $H$. spumosa was showed the highest intensity in posterior intestine (6.84) and comparatively lower intensity were found in caecum (5.33) (Table II).

The intestine of Long-Evans is a coil and long tube and its wall is consists of serosa, muscularis, submucosa and mucosa. These layers are arranged serially one below the other. The muscularis consists of thick circular and thin longitudinal muscle layer. The parasites were found firmly attached to the intestinal wall with their adhesive organs bearing gland cells or hooks by which they remain attached to the host mucosa. The parasites damaged the walls at the sites of their attachment. This disruption was mainly due to the action of sucker of helminth parasites. As a result the intestinal wall was heavily destroyed. In some cases, tissues were found to disappear completely (Fig. 1-3). Thus vacular structure appeared. Fibrosis or necrosis and few pigments were also observed.

Table I. Organ wise prevalence and intensity of helminth parasites in Long-Evans.

\begin{tabular}{l|c|c|c|c|c}
\hline Organ & $\begin{array}{c}\text { Total no. of } \\
\text { hosts examined }\end{array}$ & $\begin{array}{c}\text { Total no. of } \\
\text { hosts infected }\end{array}$ & $\begin{array}{c}\text { Prevalence } \\
(\%)\end{array}$ & $\begin{array}{c}\text { Total no. of } \\
\text { worms collected }\end{array}$ & $\begin{array}{c}\text { Intensity } \\
( \pm \text { SD })\end{array}$ \\
\hline Stomach & 48 & 0 & 0 & 0 & 0 \\
Doudenum & 48 & 21 & 43.75 & 46 & 2.19 \\
Ant. Intestine & 48 & 36 & 75 & 1848 & 51.33 \\
Post. Intestine & 48 & 37 & 77.08 & 729 & 19.72 \\
Caecum & 48 & 46 & 95.83 & & \pm 2.3 \\
& & & & & 20.23 \\
\hline
\end{tabular}


Table II. Prevalence and intensity of organ wise each species of helminth parasites in Long-Evans.

\begin{tabular}{ll|c|c|c|c|c}
\hline Organ & & V. nana & H. diminuta & C. dispar & H. spumosa & S. muris \\
\hline \multirow{5}{*}{ Doudenum } & No.of hosts infected & 20 & 2 & 0 & 0 & 0 \\
& No. of worms collected & 44 & 2 & 0 & 0 & 0 \\
& Prevalence \% & 41.66 & 4.16 & 0 & 0 & 0 \\
& Intensity & 2.20 & 1.00 & 0 & 0 & 0 \\
\hline \multirow{5}{*}{ Ant. Intestine } & No.of hosts infected & 28 & 24 & 0 & 0 & 0 \\
& No. of worms collected & 1728 & 120 & 0 & 0 & 0 \\
& Prevalence \% & 53.33 & 50.00 & 0 & 0 & 0 \\
& Intensity & 61.71 & 5.00 & 0 & 0 & 0 \\
\hline \multirow{5}{*}{ Post. Intestine } & No.of hosts infected & 0 & 2 & 25 & 19 & 26 \\
& No. of worms collected & 0 & 3 & 247 & 130 & 349 \\
& Prevalence \% & 0 & 4.17 & 52.08 & 39.58 & 54.17 \\
& Intensity & 0 & 1.50 & 9.88 & 6.84 & 13.42 \\
\hline \multirow{5}{*}{ Caecum } & No.of hosts infected & 0 & 10 & 29 & 30 & 30 \\
& No. of worms collected & 0 & 15 & 342 & 160 & 415 \\
& Prevalence \% & 0 & 20.83 & 60.42 & 62.50 & 62.50 \\
& Intensity & 0 & 1.50 & 11.79 & 5.33 & 13.83 \\
\hline
\end{tabular}

Total number of host examined was 48, No parasite was found in the stomach.

Khanum and Arefin (2003) reported that in laboratory mice the prevalence of infestation was highest in anterior intestine (70.5\%) and the lowest in stomach (5.83\%). The intensity of infestation in laboratory mice was found lowest in duodenum and the highest in anterior intestine.

From the above investigation indicates that the intestine and caecum is the favorite niche of most parasites where they were heavily abundant.

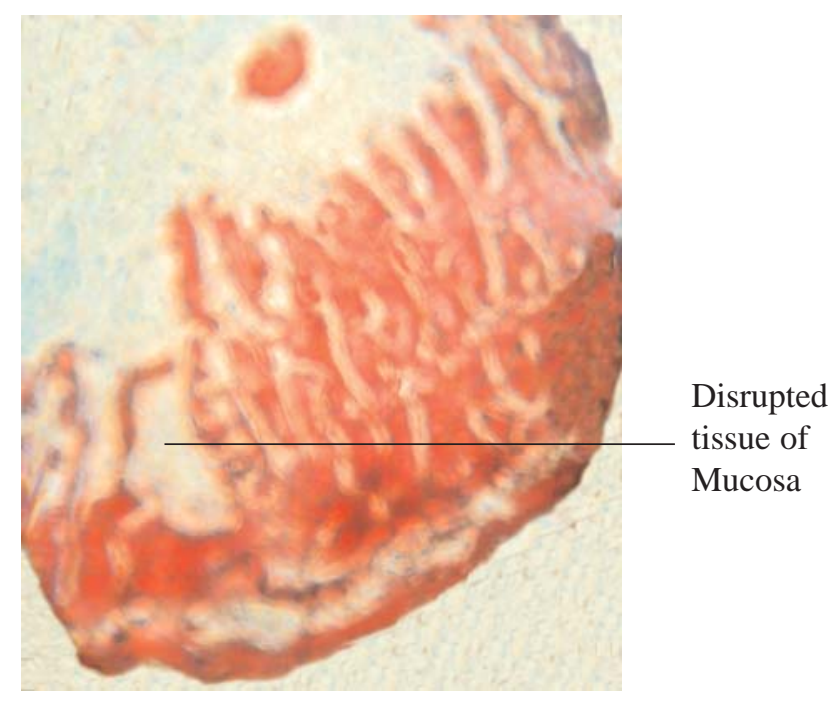

Fig 1. Transverse section of infected intestine of LongEvans (40 x 10).

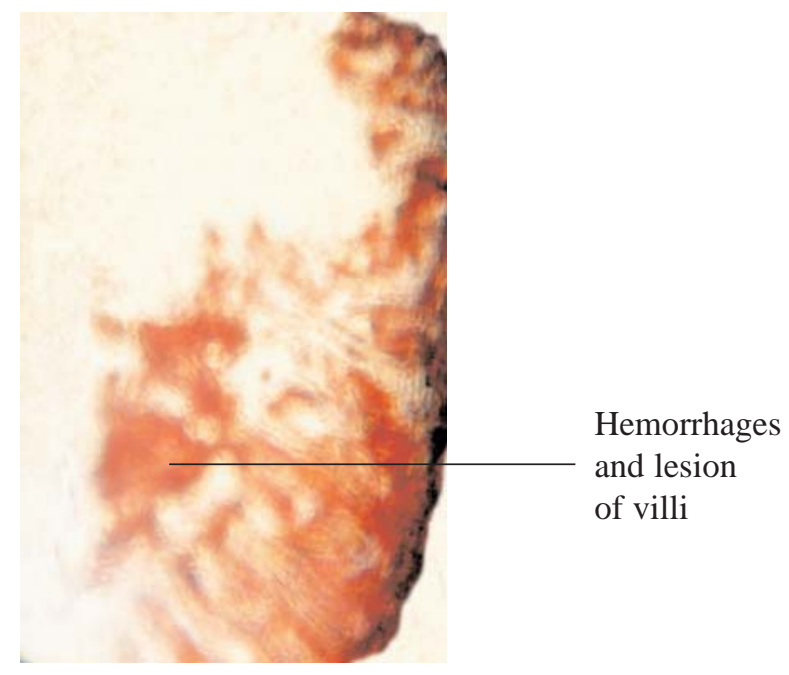

Fig 2. Transverse section of infected intestine of Long-Evans (40 x 10).

Abundance of $V$. nana was highest in anterior part of the intestine (small intestine) in Long-Evans in present observation supports Jawdat and Mahmoud (1980) who also found similar distribution.

From histopathological investigation it was observed that, the intestine was affected and tissues were damaged seriously by $V$. nana and $H$. diminuta. Degenerated tissues were observed within the folds around the parasites. The muscularis mucosa was found to be disrupted and damaged by the parasites. 


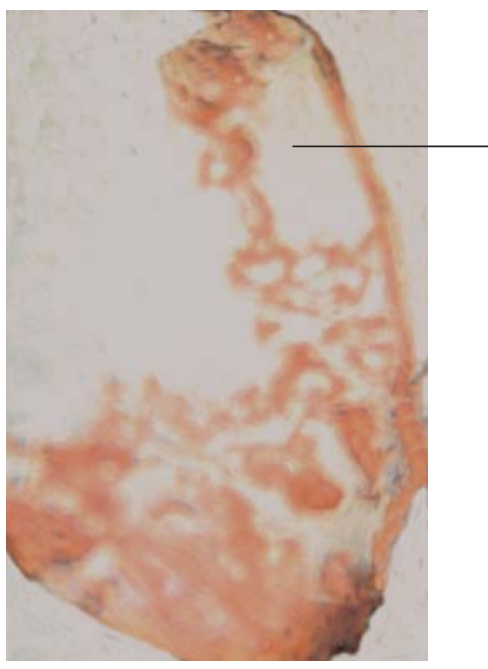

Destructed and damaged mucosa and submucosa layers

Fig 3. Transverse section of infected intestine of LongEvans (40 x 10).

\section{Conclusion}

The histopathological observation showed that the presence of parasites within the organs causes hazard to the host in many ways. Heavy infection to the intestine may cause perforation and thereby physiological function might be abnormal. Damage of villi tissues may cause many reactions to the host.

\section{Acknowledgement}

The authors wish to offer thanks to Dr. M. Formuzul Haque, Ex. Director, IFST, BCSIR, Dhaka for providing laboratory facilities during the research work. The authors are indebted to Dipa Islam, Scientific Officer, IFST, BCSIR, Dhaka, for her co-operation and helpful guidance. The authors are also grateful to M. Abdur Razzak, Senior Laboratory Attendant, Animal Research Section, IFST, BCSIR, Dhaka for his assistance during this research.

\section{References}

Alam M. S., Khanum H., and Nessa Z. (2003) Helminth infection in laboratory rat strain, Long-Evans (Rattus norvegicus Berkenhout, 1769). Bangladesh J. Zool. 31(2): 221-225.

Bhuiyan A. I., Ahmed T. A., and Khanum H. (1996) Endoparasitic Helminths in Rattus rattus Linnaeus and Bendicota bengalensis Gray. J. Asit. Soc. Bangladesh, Sci. 22: 189-194.

Cable R. M. (1963) An illustrated laboratory manual for Parasitology. Burgress Publishing Company, Minneapolis. PP. 169.

Huq M. M. (1969) A survey of the helminth parasites of roof rats Rattus rattus, digger rats Bendicota bengalensis and mole Scalopus scalopus in Mymensingh district, East Pakistan. Pak. J. Vet. Sci. 3: 65-68.

Jawdat S. Z., and Mahamoud S. N. (1980) The incidence of cestoidean and acanthocephalan parasites of some rodents in Iraq. Bull. Nat. Hist. Res. Centre. 7(4): 55-71.

Khanum H., and Arefin N. (2003) Helminth Burden in Laboratory mice, Mus musculus. Bangladesh J. Zool. 31: 117-123.

Oldham J. N. (1931) The helminth parasites of common rats. J. Helminth. 9: 49-60.

Shaha J. G. (1974) Taxonomy of some of the helminths of house rats, house mice and house shrews of Dacca city. M. Sc. thesis. University of Dhaka, Bangladesh. PP. 120.

Stanley S. L. J. R., and Virgin, I. V. H. W. (1993) Scid as models for parasitic infections. Parasitol Today. 9: 406411.

Received : September, 03, 2008;

Accepted : December, 18, 2008 
Jahangir, Mondal, Nada, Sarker, Moniruzzaman and Hossain. 
